\title{
Effect of Educational Games on Self-concept Levels of Inclusive Students Studying in Secondary Schools*
}

\author{
Serhat Üstündağ ${ }^{1}$, Gülsen Özcan ${ }^{2}$ \\ ${ }^{1}$ Secondery School, Şehit Meriç Alemdar, Physical Education Teacher, Ankara, Turkey \\ ${ }^{2}$ Department of Physical Education and Sports Education, Abant İzzet Baysal University, Bolu, Turkey \\ Correspondence: Gülsen Özcan, Department of Physical Education and Sports Education, Abant İzzet Baysal University, \\ Bolu, Turkey.
}

Received: June 14, 2018

Accepted: September 13, 2018

Online Published: September 16, 2018

doi:10.11114/jets.v6i10.3365

URL: https://doi.org/10.11114/jets.v6i10.3365

\begin{abstract}
This research examines the effect of educational games on self-concept levels of inclusive students enrolled in secondary schools. The research was conducted in two secondary schools in Golbasi district of Ankara, the capital of Turkey, in the spring semester of 2015 - 2016 academic year. The research employed semi-experimental design with pretest and posttest control group. Of a total of 24 students, 12 ( 4 girls, 8 boys) were included in the experimental group and the other 12 ( 6 girls, 6 boys) were included in the control group. Educational games program, an independent variable of the research, was applied for 11 weeks, 2 lessons per week. The program that did not include educational games was applied to the control group. Self-concept Scale (SCS) was used to collect data in the research. Independent group $t$ test was used for data analysis, and for single-factor repeated measures, two-factor ANOVA test was used. The significance level was determined to be 0.05 . At the end of this research, a significant difference was found in favor of the students in the experimental group in terms of physical competence, physical appearance, peer relationships and general self-concept dimensions of the self-concept scale. On the other hand, there was not any significant difference in favor of both groups in terms of the dimension of relations with parents of the scale.
\end{abstract}

Keywords: educational games, self-concept, inclusive student

\section{Introduction}

Human being is an entity that needs to learn and teach to maintain his life. Especially in the early years of life, teaching with games serves to the child development in the easiest and in the most natural way. In this process, generally each game has a goal as well as a range of rules, enforcement, feedback and penalties (Ke, 2016; Klopferet et al., 2009, Wouters \& Van Oostendorp, 2013, Prensky, 2001). The versatile structure of game, a universal way of learning, has contributed to the arrangement of educational environments and to the use of teaching with game as a professional education tool in recent years (Garris, Ahlers, \& Driskell, 2002, Mayer, 2011, Aldrich, 2005; Vandercruysse et al., 2012, Koçyigit, Tuğluk \&Kok, 2007).

According to Piaget (1962), a child learns through games to adapt to his/her environment. Games are actions that have solid rules in their own way. According to Montaigne (1570), playing games is the most real occupation of children because children take games quite seriously (Çamliyer, 2009). Vygotsky (1967) describes games as a means that enable children to make sense and learn. Lazarus (1883) defined game as a free activity occurring spontaneously and bringing happiness. A game is an indispensable entertainment for children. Children learn to share, to act in solidarity, and to fight for an objective thanks to games (Pehlivan, 2005). One of the most functional explanations about games belongs to the famous Turkish philosopher, Mevlana. Mevlana said, "Game is in fact in the mind, but a child gets wiser by playing them" (Karakaya, 2008). As can be understood from this quote, games have a serious impact on the cognitive development of children. Through games, children learn to imitate reality in an objective way. Thus, the child experiences realistic experiences by doing daily work (such as changing clothes, washing dishes, hovering, impersonating social roles, etc.) or by acting important events in life (such as death and funerals) (Georges, 2007).

The action of teaching is thought to be an inherent talent in human beings (Csibra \& Gergely, 2009; Goswami, 2004; Strauss, 2005; Strauss \& Ziv, 2012; Tomasello, Kruger \& Ratner, 1993) and a simple feature of our cognitive architecture (Rodriguez, 2013). However, it is necessary to use different methods and techniques in order for the 
teaching activities, a professional occupation, to provide the desired learning (Bilen, 1996). It is unlikely that any teaching method will be valid for every course and for all students. The teacher should be able to use different teaching methods and techniques according to the students' types of learning, the feature of the subject to be taught, the facilities of the school, and the level of students. In this sense, teaching with games is one of the easiest, funniest and most effective tools for teachers (Demirel, 2002; Baykoc-Dönmez, 2000; Onay, 2006; Cangir, 2009) since educational games provide multiple benefits that enable the student to understand and evaluate him/herself, the environment and his/her friends (Tural, 2005; Onay, 2006). Furthermore, games are an essential part in the lives of especially elementary school students. Therefore, ensuring that students acquire desired behaviors through games, which are already natural ways for them to learn, will both increase the permanence of the child's learning and positively affect his/her attitude towards the lesson (Özden, 1999 ).

Today, progress in democracy and human rights has enabled disabled individuals to lead a fairer and more peaceful life in the society as well as positively affecting the society's perception of individual differences. In accordance with this purpose, schools also fulfill their duties by bringing together disadvantaged students and normal students through inclusive education (Kuz-Tayyar, 2001; Güzel-Özmen, 2003; Allen \& Cowdery, 2005; Aral, 2011; Atkın, 2013; Ministry of National Education (MoNE), 2014, Gold \& Richards, 2012; Vislie, 2003; Gillet et. al, 2012). By disadvantaged children, we refer to the children who have poor comprehension abilities, social adaptation problems or do not receive adequate support from his/her family (Perner, Frith, Leslie \& Leekam, 1989; Baron-Cohen, Leslie \& Frith, 1985). Thanks to the inclusive education in schools, individual education programs are prepared for each of these students and development of their affective, cognitive and psychomotor behaviors are supported (Allen \& Cowdery, 2005; Batu-S \& Kurcaali-Iftar 2005; Acarlar, 2013).

The main objective of educators is to ensure that each student develops as a whole in terms of all areas of development (Senemoglu, 2002; Sönmez, 2005). The perception of self-concept within the area of affective development has significant impact on development in this sense. Self-concept is about how an individual sees himself or herself rather than how others see them (Cüceloğlu, 1992; O’Mara, et al.,2006; Hofmann \& Wilson, 2010; Wilson, 2002). Perceptions about self-concept emerge with the individual's interpretation of his/her own experiences and his/her own physical, academic and social environment.

Social comparisons play an important role in this process. For example, students take the performances of their friends as a reference to evaluate their own performances (Marsh, 1992). Self-concept exhibits a private and individual characteristic. Self-concept contributes not only to the individual's perception of him/herself as a separate being, but also to the struggle of that person as a being that wants and acts to get what he/she wants.

This research aims to determine the effect of educational games on the self-concept perceptions of the students enrolled in schools with inclusive education. When the related literature was examined, no research which was conducted on this subject was found. Instead, the literature review revealed that previous studies on games and educational games focused on the academic achievement of normal students (Ören \&Avc1, 2004; Songur, 2006; Y1ldiran, 2004; Altunay, 2004, Taşl1, 2003; Tural, 2005). Therefore, this study has made it possible for us to find out about the impact of educational games on the self-concept levels of inclusive students and to see the strength of games in the education world. We also expect that that this study will inspire future studies that will boost inclusive students' learning and help them gain the habit of living together with other students. Last but not least, we believe that this study will evoke awareness for the education of inclusive students and inspire researchers to develop specially-tailored education programs for these children.

\section{Method}

\subsection{Research Design}

This research was conducted in accordance with the experimental design with pretest - posttest control group. In a study with the experimental design, individuals should be divided to experimental and control groups in an unbiased way. However, in education environments it is difficult to divide students to the groups in an unbiased way. Therefore, researchers preferred using quasi-experimental design, where available groups can be matched through certain variables and unbiased assignments can be made through these groups (Gay, Mills and Airasian, 2006).

\subsection{Study Group}

The research was conducted with 12 (4 girls, 8 boys) inclusive students (experimental group) who receive education in a secondary school in the 2015-2016 academic year in Turkey and have mental competence at a level to respond to the scale applied according to the expert's opinion and 12 ( 6 girls, 6 boys) inclusive students (control group) who are in another secondary school in Turkey and have the same characteristics. 


\subsection{Data Collection Tools}

\subsubsection{Self-Concept Scale}

Personal information form developed by the researcher and non-academic part of the Self-Concept Scale developed by Marsh (1992) and adapted to Turkish by Fer and Sönmez (2008) were employed for data collection. The scale was developed by Marsh (1992) in order to measure the multidimensional self-concept perceptions of the elementary school students. Non-academic four sub-factors of the scale are composed of the items in relation to the students' physical competence, physical appearance, peer relationships, parent relationships and general self-concept perceptions.

Internal consistency reliability coefficient calculated for the entire scale is 0.95 . Findings showed that the internal consistency reliability of factor items have an item-total correlation coefficient ranging from 0.17 to 0.65 . Alpha coefficients of the subscales were between 0.75 and 0.94 . The consistency level increases as the reliability coefficient approaches 1 whereas it decreases as the reliability coefficient approaches 0 . In accordance with the specified references the internal consistency reliability coefficients of the scale were found at a good level (Fer and Sönmez, 2008)

\subsection{Research Process Procedure}

The research process firstly began with the literature search on self-concept and educational games. Since the study group is a group that needs special education, in order to find out whether SCS is suitable for this group, confirmation was received from the researchers (Fer\&Sönmez, 2008) who performed the validity and reliability study of the scale whether the assessment instrument is suitable to the group. In addition, positive opinion was received in regard to the scale items to be applied to the students from the School Counselor teacher who prepared the individual education program for students and from the teacher who taught Turkish to the students. Afterwards, parental permission for the research and ethical permission indicating voluntary participation of the students in this application were received. After receiving the consent of the related people, the experimental process was planned and the activity plan predicted to take 11 weeks was prepared. The prepared draft plan was reviewed by five specialists, two program development specialists, two specialist physical education teachers and an assessment and evaluation specialist, and the draft event plan was given the final form considering the expert opinions. Later, necessary correspondences were made with the related institutions and permissions were taken from the schools where the application would be made. Afterwards, we decided that one of the researchers of this research, who is also the physical education teacher in one of the schools where the research would be carried out, would conduct the study in the experimental group. On the other hand, in the other public school in the area where the research was conducted, the control group studies were carried out with the inclusive students with similar characteristics. The teacher working in the control group was informed about the points to pay attention during the research process and was given instructions to not carry out any educational games with the students during the semester. On a day specified by the school administration, the researcher taught a lesson through educational games to the experimental group for two hours (40+40 minutes) a week for 11 weeks. At the end of the experimental period, research findings were discussed according to pretest-posttest results given before and after the research.

\subsection{Data Analysis}

In data analysis, firstly in order to test the difference between the self-concept scores of the experimental and control groups, independent group's t test was performed. Furthermore, since the number of subjects was limited in both groups (Experiment=12 persons, Control=12 persons), Kolmogorov Smirnov test and homogeneity test were performed to see whether the groups were normally distributed. The first analyses showed that there was no significant difference between the groups ( $p>0.05$ ) and the groups were normally and homogeneously distributed ( $>>0.05)$. For the comparison of pre- and post-test scores of the research data, two factor Anova model was used for repeated measures in the single factor (Büyüköztürk, 2004). 


\section{Findings and Discussion}

This section includes findings that show the effect of educational games on non-academic self-concept levels of inclusive students and discussions about these findings.

Table 1. Pretest Posttest Physical Competence Anova Results of the Experimental and Control Group Students

\begin{tabular}{llllll}
\hline Source of Variance & Sum of Squares & sd & $\overline{\mathrm{x}}$ & $\mathrm{F}$ & $\mathrm{p}$ \\
\hline Intergroup & 11.02 & 1 & 11.02 & .20 & .659 \\
Error & 1213.45 & 22 & 55.15 & & \\
Intragroup (Measurement) 72.52 & 1 & 72.52 & 13.89 & $.001^{*}$ \\
Group*Measurement & $\mathbf{5 4 . 1 8}$ & $\mathbf{1}$ & $\mathbf{5 4 . 1 8}$ & $\mathbf{1 0 . 3 8}$ & $\mathbf{. 0 0 4 *}$ \\
Error & 114.79 & 22 & 5.21 & & \\
\hline
\end{tabular}

$*_{p}<.05$

Table 1 demonstrates a significant difference in favor of the experimental group between the pretest-posttest measurements of the experimental and control group students. $\left(\mathrm{F}_{(1-22)}=10,38, \mathrm{p}<0.05\right)$. While the pre-experiment physical competence perception average of the inclusive student in the experimental group was 28.75 , it increased up to 33.33 after the experiment. Physical competence perception average of the inclusive students in the control group, however, increased from 31.83 up to 32.16 . This result is an expected and desired one. In other words, we can say that the educational games variable used in the research helped the students perceive themselves more positively in terms of physical competence. The research findings are also supported with the findings of the research conducted by Özcan and Üstündağ (2017) with the students receiving normal education. The researchers used the non-academic self-concept scale developed by Marsh (1992) and adapted to Turkish by Yildiz and Fer, and found a significant difference in favor of the experimental group in the physical competence dimension of the scale. The literature review also revealed certain studies supporting these findings. According to Doğanay (2002), educational games develop individuals' physical and mental talents and artistic and aesthetic skills, make life enjoyable, and allow the information learned to be reinforced and repeated in a more comfortable environment. In physical games, the respiratory and circulatory systems of the children develop thanks to physical activities. Moreover, muscular and skeletal system development is supported. In both physical and educational games, the child is naturally prepared for the development of motor skills such as speed, strength and endurance. It helps strengthen the reflexes. Children learn and develop the limits of physical overloading and fatigue. The most positive effect on the development of balance and coordination of the children is games (Onay, 2007). Şirinkan (2011) searched the effect of sportive educational games on the physical developments of disabled students, and as a result of the research, significant differences were found in terms of the flexibility parameters of the students. This is another result that supports the results of this research.

Table 2. Pretest and Posttest Physical Appearance Anova Results of the Experimental and Control Group Students

\begin{tabular}{llllll}
\hline Source of Variance & Sum of Squares & $\mathrm{sd}$ & $\overline{\mathrm{x}}$ & $\mathrm{F}$ & $\mathrm{p}$ \\
\hline Intergroup & .083 & 1 & .08 & .001 & .97 \\
Error & 1492.91 & 22 & 67.86 & & \\
Intragroup (Measurement) & 126.75 & 1 & 126.75 & 38.59 & $.00^{*}$ \\
Group*Measurement & $\mathbf{1 0 8 . 0 0}$ & $\mathbf{1}$ & $\mathbf{1 0 8 . 0 0}$ & $\mathbf{3 2 . 8 8}$ & $\mathbf{. 0 0}^{*}$ \\
Error & 72.25 & 22 & 3.28 & & \\
\hline
\end{tabular}

$* p<.05$

Table 2 demonstrates a significant difference in favor of the experimental group between the pretest-posttest physical appearance scores of the experimental and control group students $\left(\mathrm{F}_{(1-22)}=32.88, \mathrm{p}<0.05\right)$. While the pre-experiment physical appearance perception average of the inclusive students in the experimental group was 29.33 , it increased up to 35.58 after the experiment. The average physical appearance perception of the inclusive students in the control group, however, increased from 32.41 up to 32.66. This result is an expected result. In other words, we can say that the educational games variable used in the research helped the students perceive themselves more positively in terms of physical appearance. A study conducted by Özcan and Üstündağ (2017) also supported these findings. Accordingly, the research conducted with normal students at the eighth grade revealed a significant difference in favor of the experimental group in the physical appearance dimension of the self-concept scale. Games allow the child to direct his aggression in a positive direction, helping to control excess energy. The feeling of enthusiasm, excitement and success that the child feels while playing helps to develop his/her self-confidence. Furthermore, through games, the child can get to know about his/her body, use it as he/she wants, and control him/herself (MoNE, 2014). 
Table 3. Pretest-Posttest Peer Relationships Anova Results of the Experimental and Control Group Students

\begin{tabular}{llllll}
\hline Source of Variance & Sum of Squares & sd & $\bar{x}$ & $\mathrm{~F}$ & $\mathrm{p}$ \\
\hline Intergroup & 58.52 & 1 & 58.52 & 1.07 & .31 \\
Error & 1201.45 & 22 & 54.61 & & \\
Intragroup (Measurement) & 31.68 & 1 & 31.68 & 3.13 & .09 \\
Group*Measurement & $\mathbf{8 2 . 6 8}$ & $\mathbf{1}$ & $\mathbf{8 2 . 6 8}$ & $\mathbf{8 . 1 9}$ & $\mathbf{. 0 0 9 *}$ \\
Error & 222.12 & 22 & 10.09 & & \\
\hline
\end{tabular}

$* p<.05$

Table 3 demonstrates a significant difference in favor of the experimental group between pre-experiment and post-experiment peer relationships scores of the experimental and control group students $\left(\mathrm{F}_{(1-22)}=8,19, \mathrm{p}<0.05\right)$. While the pre-experiment peer relationship perception average of the inclusive students in the experimental group was 30.08, it increased up to 34.33 after the experiment. Peer relationship perception average of the inclusive students in the control group, however, decreased from 30.50 to 29.50. This research result is an expected and desired one. In other words, we can say that the educational games variable used in the research helped the students perceive themselves more positively in terms of peer relationships. Likewise, Özcan and Üstündağ (2017) found that in the physical education lesson taught with educational games, peer relationship perceptions of the eighth grade students significantly changed in the experimental group.

Games support behaviors like respecting others, not telling lies, controlling oneself within a group, friendship and sharing. They help students make friends, feel themselves a part of their groups and support each other. In this way, children learn teamwork and understand the importance of working together to achieve a goal. Games provide the environment where both physical and mental abilities can be tried and repeated as much as desired to achieve self-confidence and mastery (Moyles, 1991). Games are a very important factor that ensures psychological development of children. Through games, children can express themselves more comfortably and establish relations with other children more easily. Playing with peers plays an important role in gaining the ability to establish social relations. Group games ensure the social and emotional development of children. Within a group, children learn about various social relations which help them to adapt to social environment. Children find the opportunity to express themselves within their environment especially through role playing in a group environment. Games, where, as previously mentioned, children find the opportunity to express themselves without the fear of making mistakes, also develop children's self-confidence (Sevinç, 2004).

Saban (2002) defines games as the activities that allow children to solve their emotional conflicts, develop various hypotheses about the world and test them, discover various social roles and status in the society and develop social skills that will help them establish good relationships with their peers.

According to Onay (2007), the play group starting with the family members is later replaced by peers with whom children establish mutual relationships. In this way, the concepts such as us, you and them begin to develop. Learning process starts with games. For this reason, games can be used as an educational tool especially at preschool and primary school levels. Games are an activity that gives comfort, fun, joy and pleasure. Studies conducted in this respect also seem to support these findings. A study by Kabasakal, Girli, Okun, Çelik and Vardarli (2008) examined inclusive students, peer relationships and peer abuse. Their study aimed to determine the position of inclusive students within peer relationships, the ways of their perception and the dimensions of peer abuse and to suggest solution-oriented implementations to educators. The sample group was composed of a total of 329 students from three elementary schools, 16 of whom were inclusive students. As the assessment tool, "Sociometry", "Who is this?" and "Peer Abuse Questionnaire for Students" were employed. The study found that inclusive students are not preferred by their friends for cooperative works in the classroom, and are perceived as problematic in terms of adaptation and communication. A comparison of the findings of their study with the findings of the current study will reveal that inclusive students, whose perceptions of peer relations are developed through educational games, will be more self-confident, which will in turn have a positive impact on normal students' perceptions of inclusive students.

Table 4. Pretest-Posttest Parent Relationships Anova Results of the Experimental and Control Group Students

\begin{tabular}{llllll}
\hline Source of Variance & Sum of Squares & sd & $\bar{x}$ & $\mathrm{~F}$ & $\mathrm{p}$ \\
\hline Intergroup & 33.33 & 1 & 33.33 & .54 & .46 \\
Error & 1339.33 & 22 & 60.87 & & \\
Intragroup (Measurement) & .33 & 1 & .33 & .034 & .85 \\
Group*Measurement & 21.33 & 1 & 21.33 & 2.15 & .15 \\
Error & 218.33 & 22 & 9.92 & & \\
\hline
\end{tabular}

$*_{p}<.05$

According to the anova result of the experimental and control group students, there was not any significant difference between the pretest and posttest measurements of the students' parent relationships $\left(\mathrm{F}_{(1-22)}=2,15, \mathrm{p}>0.05\right)$. While the 
pre-experiment parent relationship perception average of the inclusive students in the experimental group was 34.91, it increased up to 36.08 after the experiment. The average parent relationship perception of the inclusive students in the control group, however, decreased from 37.91 to 36.41. In other words, we can say that the educational games variable used in the research did not sufficiently help the students perceive themselves more positively in terms of parent relationships. A study conducted by Özcan and Üstündağ (2017) also supported these findings: there was not a significant difference in the experimental and control groups in regard to the students' parent relationships in the physical education lesson conducted with the eighth grade students and taught with educational games. On the other hand, Acat (2009) and Akpınar (2010) stated that games have an important impact on parental participation, school and education involvement and help the children continue to school eagerly, to increase their self-respect and to develop positive attitude toward school. This means that both school and family mutually affect each other. Most of the children games have a social structure. Through games, children gain gender identity and assume the roles of family members and learn the responsibilities and personalities of these members. Children understand the occupational groups and their roles, and learn to solve problems together thanks to games (Akandere, 2006). In the light of these explanations, it can be deduced that children's parent relationships can be improved through educational games. The fact that the findings of this research did not produce such an outcome may be related to the age characteristics of the students forming the research group. The children between 11 and 14 may feel themselves closer to their peers than their family members (Rizzo, 1988), which have a direct impact on their relations with their peers and family members. In fact, the results obtained in the previous peer relationships sub-dimension of the scale also support this result.

Table 5. Pretest-Posttest General Self-Concept Anova Results of the Experimental and Control Group Students

\begin{tabular}{llllll}
\hline Source of Variance & Sum of Squares & $\mathrm{sd}$ & $\overline{\mathrm{x}}$ & $\mathrm{F}$ & $\mathrm{p}$ \\
\hline Intergroup & 1.33 & 1 & 1.33 & .022 & .88 \\
Error & 1353.58 & 22 & 61.52 & & \\
Intragroup (Measurement) & 8.33 & 1 & 8.33 & .50 & .48 \\
Group*Measurement & $\mathbf{9 0 . 7 5}$ & $\mathbf{1}$ & $\mathbf{9 0 . 7 5}$ & $\mathbf{5 . 4 5}$ & $\mathbf{. 0 2 9}$ \\
Error & 365.91 & 22 & 16.63 & & \\
\hline
\end{tabular}

$* p<.05$

As understood from the table above, a comparison of pretest-posttest scores of the experimental group and control groups demonstrate a significant difference in favor of the experimental group $\left(\mathrm{F}_{(1-22)}=5,45, \mathrm{p}<0.05\right)$. While the pre-experiment self-concept perception average of the inclusive students in the experimental group was 33.08, it increased up to 36.66 after the experiment. Self-concept perception average of the inclusive students in the control group, however, decreased from 35.50 to 33.58. In other words, we can say that the educational games variable used in the research helped the students perceive themselves more positively in terms of self-concept. When the literature in relation to the subject is examined, Özcan and Üstündag (2017)'s similar study found that the self-concept perceptions of the eighth grade students decreased both in experimental and control groups in the posttest. This difference can be considered to be related to the difference in the study group. As is known, the high school entrance exam that eighth grade students attend in the spring semester in Turkey may have affected their self-concept perceptions negatively. A study indirectly supporting this result was conducted by Demirci et al. (2006), who asked the opinions of primary school first grade teachers about the effect of education with games on the child development: $99 \%$ of the teachers stated that education with games is important and increases the academic achievement of children. Furthermore, $97 \%$ of the teachers said that education with games facilitates children's learning and $95 \%$ of them said that education with games gives the chance to better understand the child. Also, $93 \%$ of the teachers stated that games and education with games are one of the basic needs of children and substantially affect their general development. In addition, Erdoğan (2006) examined the effects of creative drama studies conducted with 8th grade students having depressive symptoms on the depressive symptoms and self-concepts of these students. The study findings demonstrated that creative drama studies led to an apparent regression in the depressive symptoms of the 8th grade students and a positive increase in their self-concept levels. Considering the fact that creative drama is also an educational game, we can say that this study indirectly supports this research result.

\section{Conclusion}

When the general results of this research examining the effect of the educational games on the self-concept levels of the inclusive students are evaluated, it is seen that pretest scores of the experimental and control group students are at a good level in all sub-dimensions of the non-academic self-concept scale used in the research while in posttest scores, except for parent relationship sub-dimension, a significant difference in favor of the experimental group is seen in all sub-dimensions. This research result is an expected and desired one for the researchers. Detailed results of the research are as follows; 
1. Physical competence perceptions of the inclusive students in the experimental group are significantly different compared to the students in the control group.

2. Physical appearance perceptions of the inclusive students in the experimental group are significantly different compared to the students in the control group.

3. Peer relationship perceptions of the inclusive students in the experimental group are significantly different compared to the students in the control group.

4. There was not any significant difference between the parent relationship perceptions of the inclusive students in the experimental group and the inclusive students in the control group.

5. Self-concept perceptions of the inclusive students in the experimental group are significantly different compared to the students in the control group.

\section{Recommendations}

1. The fact that this research has been carried out with a small research group is one of the major limitations of this research in terms of its generalizability. Therefore, the research can be applied to more students.

2. The limited number of similar researches in regard to the research subject has limited the comparison and evaluation of the research findings. We think that new researches on this subject will contribute to the field.

3. This research is limited only to experimental and control group independent variables. We recommend that researchers who will conduct research on this subject should add richness to research subject with different variables such as gender, class, academic average.

4. This research has proved that educational games have a positive and significant effect on inclusive students. Therefore, in-service trainings about educational games can be organized for all teachers who have inclusive students in their classes.

\section{Acknowledgments}

This study is produced from a section of the master's thesis conducted on Physical Education and Sports Teaching at Abant Izzet Baysal University, Institute of Education Sciences and supervised by Asst. Prof. Dr. Gülsen Özcan.

\section{References}

Acarlar, F. (2013). Inclusion model and exceptional children' properties. B. Sucuoğlu ve H. Bakkaloğlu (Ed). Mainstreaming in preschool education (pp. 21-74). Ankara: Kök Publishing.

Acat, M. B. (2009). The scale studies about parents attitude relative to school and participation levels of curriculum. Third. educational administration Congress, Retrieved January 27, 2017 from http://www.pegem.net/akademi/kongrebildiri

Akandere, M. (2006). Educational school games. Ankara: Nobel Publishing.

Aldrich, C. (2005). Learning by doing: The Comprehensive guide to simulations, computer games, and pedagogy in e-learning and other educational experiences. San Francisco, CA: Pfeiffer

Allen, K. E., \& Cowdery, G. E. (2005). The exceptional child: inclusion in early childhood education. USA: Thomson.

Altunay, D. (2004). The effect of mathematics lesson taught by using instructional games on students' achievement and permanency. Master's Thesis, Gazi University, Turkey.

Aral, N. (2011). Mainstreaming education at preschool. Istanbul: Morpa Publishing.

Atkın, B. (2013). Mainstreaming. Hasan Avcıoğlu (Ed.), Special training at primary education. Ankara: Nobel Pres, 19-64.

Baron-Cohen, S., Leslie, A. M., \& Frith, U. (1985). Does the autistic child have theory of mind? Cognition, 21, 37-46. https://doi.org/10.1016/0010-0277(85)90022-8

Batu, S., \& Kircaali-Iftar, G. (2005). Inclusion. Ankara: Kök Publishing.

Baykoc-Donmez, N. (2000). Game book. Istanbul, Esin publishing..

Bilen, M. (1996). Instruction from planing to application. Ankara: Anı Publishing.

Büyüköztürk, Ş. (2004). Sosyal bilimler için veri analizi el kitabl. Ankara: Pegem A Publishing, Turkey.

Çamliyer, H. (2009). Child performance education. Celal Bayar University Press, Turkey. 
Cangir, M. (2009). İlkoğretim din kültürü ve ahlak bilgisi derslerinde eğitsel oyun yönteminin uygulanma durumu /Tuzla Örneği. Master's Thesis, Yeditepe University, Turkey.

Csibra, G., \& Gergely, G. (2009). Natural pedagogy. Trends in Cognitive Sciences, 13, 148-153. https://doi.org/10.1016/j.tics.2009.01.005

Cüceloğlu, D. (1992). Human and behavior. Istanbul: Remzi Pess.

Demirci, E., Demirci, N., \& Toptaş, P. (2006). Illköğretim 1. kademe sınlf öğretmenlerine göre oyunla eğitimin çocuğun gelişimine ait görüsslerinin incelenmesi. The 9 th International Sports Sciences Congress, Turkey.

Demirel, Ö. (2002). Teaching art from planning to evaluation, Pegem Publishing, Turkey.

Doğanay, H. (2002). Geography teaching methods. Istanbul: Akif Publishing.

Erdoğan, G. (2006). The effects of creative drama on the self concept and depressive symptoms of $8^{\text {th }}$ grade (ages 14-15) students with depressive symptoms. Master's Thesis, Gazi University, Turkey.

Fer, S., \& Yıldız, G. (2008). Validity and reliability of the "Self Description Questionnaire-I". Journal of Education Faculty, Yüzüncüyll, 5(11), 209-232.

Garris, R., Ahlers, R., \& Driskell, J. E. (2002). Games, motivation, and learning: A Research and practice model.

Gay, L. R., Mills, G. E., \& Airasian, P. (2006). Educational research: Competencies for analysis and applications (8th ed.). Upper Saddle River, New Jersey: Prentice Hall.

Georges, R. A. (2007). Eğlence ve oyunlar (Çev. D. F. Korkmaz). Millî Folklor Dergisi, 74, 129-136.

Gillet, N., Vallerand, R. J., \& Lafrenière, M. A. K. (2012). Intrinsic and extrinsic school motivation as a function of age: The mediating role of autonomy support. Social Psychology of Education, 15, 77-95. https://doi.org/10.1007/s11218-011-9170-2

Gold, M. E., \& Richards, H. (2012). To label or Not to label: The Special education question for African Americans. Educational Foundations, Winter-Spring 2012. Retrieved January 27, 2017 fromhttp://files.eric.ed.gov/fulltext/EJ968822.pdf.

Goswami, U. (2004). Neuroscience and education. British. Journal of Educational Psychology, 74, 1-14. https://doi.org/10.1348/000709904322848798

Güzel, Ö. R. (2003). Kaynaştırma ortamlarında ögretimsel düzenlemeler. A. Ataman. (Ed). Özel gereksinimli çocuklar ve özel eğitime giriş, Ankara: Gündüz Publishing.

Hofmann, W., \& Wilson, T. D. (2010). Consciousness, introspection, and the adaptive unconscious. In B. Gawronski, \& B. K.Payne (Eds.),Handbook of implicit social cognition(pp.197-215). New York, NY: Guilford Press.

Kabasakal, Z., Girli, A., Okun, B., Çelik, N., \& Vardarl1, G. (2008). Disabled students, Coequal relations and their abuse. Journal of Education Faculty, Dokuz Eylül University, 23, 169-176.

Karakaya, Z. (2008). Language and game training. Samsun: Yazı Publishing, Turkey.

Ke, F. (2016). Designing and integrating purposeful learning in gameplay: A Systematic review. Educational Technology Research \& Development, 64(2), 219-244. https://doi.org/10.1007/s11423-015-9418-1

Klopfer, E., Osterweil, S., \& Salen, K. (2009). Moving learning games forward. Cambridge, MA: The Education Arcade.

Koçyiğit, S., Tuğluk, M. N., \& Kök, M. (2007). Play as educational activity in the child's development process. Journal of Jokkef, 16, 326-342.

Kuz, T. (2001). Attitudes about inclusive education. Ankara: Prime Minister Publishing, Turkey.

Marsh, H. W. (1992). Self description qustionnaire (SDQ) I: A theoretical and empirical basis for the measurement of multiple dimensions of preadolescent selfconcept. An interim test manual and research monograph. Macarthur, New South Wales, Australia: University of Western Sydney, Faculty of Education. Retrieved April 12, 2017, http://self.uws.edu.au/Research\%20Focus/self_instruments.htm

Mayer, R. E. (2011). Multimedia learning and games. In S. Tobias \& J. D. Fletcher (Eds.), Computer games and instruction (pp. 281-305). Charlotte, NC, US: IAP Information Age Publishing.

Ministry of National Education (2014). Child development and activity of game at special education. Ministry of education Press, Turkey.

Moyles, J. R. (1991). Just playing?. Open University Press: Philadelphia. 
Nind, M., Flewitt, R., \& Theodorou, F. (2014). Play and inclusion. In K Cologne(Ed) Inclusion in The early: Right fromthe start (pp.341-359). South Melbourne, Australia: Oxford University Press.

O’Mara, A. J., Marsh, H. W., Craven, R. G., \& Debus, R. L. (2006). Do self-concep it interventions make a difference? A synergisticble and of construct validation and meta-analysis. Educational Psychologist, 41(3), 181-206. https://doi.org/10.1207/s15326985ep4103_4

Onay, C. (2006). Training with game and multible intelligence. Ankara: Nobel Publishing, Turkey.

Ören, F., \& Avc1, D. (2004). The effect of educational game teaching on academic achievement in science education course in subject of "solar system and planats" Ondokuz Mayls University, Journal of Education, 18, 67-76.

Özcan, G., \& Üstündağ, S. (2010). Effect on students' self description levels of implementing educational game in physical education course. $4^{\text {th }}$ International Balkan Conference in Sport Sciences, Turkey.

Özden, M. Y., Çağıltay, N., \& Çagıltay, K. (1999). Teknoloji ve Eğitim: Ülke Deneyimleri ve Turkiye için Dersler. Retrieved November 17, 2017 from http:// 144122,53,200/myozden/teknosan.htm

Pehlivan, H. (2005). Game and Learning. Ankara: Anı Press, Turkey.

Perner, J., Frith, U., Leslie, A. M., \& Leekam, S. R. (1989). Exploration of the autistic child's theory of mind: knowledge, belief, and communication. Child Development, 60 (3), 689-700. https://doi.org/10.2307/1130734

Piaget, J. (1962). Play, dreams and imitation in childhood. New York: Norton.

Prensky, M. (2001). Digitalgame-basedlearning. New York, NY: McGraw-Hill.

Rizzo, T. A. (1988). The relationship between friendship and sociometric judgments of peer acceptance and rejection. Child Study Journal, 18(3), 161-191.

Rodriguez, V. (2013). The human nervous system: a framework for teaching and the teaching brain. Mind, Brain, and Education, 7, 2-12. https://doi.org/10.1111/mbe.12000

Saban, A. (2002). Multiple intelligence training. Ankara: Nobel Press, Turkey.

Schnabel, K., \& Asendorpf, J. B. (2010). The self-concept: New insights from Implicit measurement procedures. In I. B. Gawronski, \& B. K. Payne (Eds.), Handbook of implicit social cognition (pp. 408-425). New York, NY: Guilford Press.

Senemoğlu, N. (2002). Development, learning and teaching. Ankara: Gazi Pess.

Sevinç, M. (2004). Development of early childhood and game at education. Istanbul: Morpa Publishing, Turkey.

Şirinkan, A. (2011). Investigation of the effect of sports education games on 10-15 age deaf student's physical development. Selçuk University, Journal of Physical Education, 13, 74-80

Songur, A. (2006). The effect of mathematics success level of the students of subjects of the explanations with letter and equations learning with games and word puzzle. Master's Thesis, Marmara University, Turkey.

Sönmez, V. (2005). Curriculum development: teacher handbook. Ankara: Anı Publishing, Turkey.

Standage, M., Duda, J. L., \& Ntoumanis, N. ( 2005). A test of self-determination theory in school physical education. British Journal of Education Psychology, 75(3), 411-433. https://doi.org/10.1348/000709904X22359

Strauss, S. (2005). Teaching as a natural cognition and its implications for teacher education. In D. Pillemer\& S. White (Eds.), Developmental psychology and the social changes of our time (pp. 368-388). New York: Cambridge University Press. https://doi.org/10.1017/CBO9780511610400.016

Strauss, S., \& Ziv, M. (2012). Teaching is a natural cognitive ability for humans. Mind, Brain, and Education, 6, 186196. https://doi.org/10.1111/j.1751-228X.2012.01156.x

Taşl1, F. (2003). Effects of game techniques on achievement in English teaching in primary school. Master's Thesis, Niğde University, Turkey.

Taylor, I. M., \& Ntoumanis, N. (2007). Teacher motivational strategies and student self-determination in physical education. Journal of Educational Psychology, 99(4), 747-760. https://doi.org/10.1037/0022-0663.99.4.747

Tomasello, M., Kruger, A. C., \& Ratner, H. H. (1993). Cultural learning. Behavioral and Brain Sciences, 16, 495-552. https://doi.org/10.1017/S0140525X0003123X

Tural, H. (2005). The Effects of Teaching Mathematics in Elemantary School by Games and Activities on Achievement and Attitude. Master's Thesis, Dokuz Eylül University, Turkey. 
Vandercruysse, S., Vandewaetere, M., \& Clarebout, G. (2012). Game-based learning: A Review on the effectiveness of educational games. In M. M. Cruz-Cunha (Ed.), Handbook of research on serious games as educational, business and research tools: Development and design (pp. 628-647). Hershey, PA: IGI Global. https://doi.org/10.4018/978-1-4666-0149-9.ch032

Vislie, L. (2003). From integration to inclusion: Focusing global trends and changes in the western European societies. Eur. J. Of Special Needs Education, 18(1),17-35. https://doi.org/10.1080/0885625082000042294

Vygotsky, L. S. (1967). Play and its role in the mental development of the child. Soviet Psychology, 12, 6-18. A stenographic record of a lecture given in 1933; included in J. S. Bruner, A. Jolly, \& K. Sylva, eds., 1976; partly produced in Vygotsky, 1978.

Wallhead, T. L., \& Ntoumanis, N. (2004). Effects of a sport education intervention on students' Motivational responses in physical education. Journal of Teaching in Physical Education, 23(1), 4-18. https://doi.org/10.1123/jtpe.23.1.4

Wilson, T. D. (2002). Strangers to ourselves: Discovering the adaptive unconscious. Cambridge: Harvard University Press.

Wouters, P., vanNimwegen, C., vanOostendorp, H., \& van der Spek, E. D. (2013). A Meta-analysis of the cognitive and motivational effects of serious games. Journal of Educational Psychology, 105(2), 249-265. https://doi.org/10.1037/a0031311

Yıldıran, N. (2004). The effect of using games and models on teaching the topic of "atomic structure and periodic table" in achievement. Master's Thesis, Marmara University, Istanbul, Turkey.

\section{Copyrights}

Copyright for this article is retained by the author(s), with first publication rights granted to the journal.

This is an open-access article distributed under the terms and conditions of the Creative Commons Attribution license which permits unrestricted use, distribution, and reproduction in any medium, provided the original work is properly cited. 